\title{
PERTAMBAHAN BOBOT DAN TINGKAT SINTASAN IKAN BETUTU (Oxyeleotris marmorata Blkr) DENGAN PEMBERIAN PAKAN YANG BERBEDA
}

\author{
Zainal Arifin ${ }^{*}$ dan Rupawan ${ }^{*}$
}

\begin{abstract}
ABSTRAK
Penelitian bertujuan untuk mengetahui pengaruh perbedaan pakan terhadap pertumbuhan dan sintasan ikan betutu (Oxyeleotris marmorata Blkr) yang dipelihara dalam hampang.

Benih ikan betutu dengan bobot rata-rata 176,2 gram dipelihara selama 180 hari dengan padat tebar 8 ekor per meter persegi. Sebagai perlakuan adalah 3 macam pakan; ikan hidup, rucah segar dan gondang segar. Pakan diberikan sekali setiap hari sebanyak 3\% bobot biomasa dan diberikan pada waktu sore hari.

Hasil penelitian menunjukkan bahwa pertambahan bobot individu antara 3 perlakuan berbeda sangat nyata $(\mathrm{P}<0.01)$. Pertambahan bobot individu per 180 hari yang paling baik didapatkan dari pemberian pakan ikan hidup, yakni 282,2 gram sedangkan dari pakan rucah segar dan gondang segar masing-masing 203,1 gram dan 170 gram. Sintasan dari ketiga perlakuan tersebut berkisar 97,91-100\%.
\end{abstract}

ABSTRACT: Growth in weight and survival rate of sand goby (Oxyeleotris marmorata Blkr) fed with life fish, fresh trash fish and mollusc. By: Zainal Arifin and Rupawan.

The objectives of the experiment were to know the effect of different feeds on the growth and survival rate of Sand goby (Oxyeleotris marmorata Blkr) reared in pen system.

Sand goby with average initial weight of 176,2 gram, were reared for 180 days at density of 8 ind $/ \mathrm{m}^{2}$. Treatment applied were three different feeds: life fish, fresh trash fish and fresh mollusc meat. The feed was given at $3 \%$ biomass weight per day.

The result of the experiment showed that there was a very significant effect of treatments on the growth rate of sand goby $(P<0.01)$. The group fed with life fish gave the highest growth rate of 282,2 gram per 180 days, while those fed with fresh trash fish and fresh mollusc meat gave 203 and 170 gram respectively. The survival rates were not significantly different $(P>0.05)$ among the treatments.

KEYWORDS: Sand goby; feed; growth; survival rate.

\section{PENDAHULUAN}

Ikan betutu (Oxyeleotris marmorata Blkr) merupakan salah satu jenis ikan air tawar yang bernilai ekonomis penting dan hidup serta berkembang biak secara liar di perairan umum di Sumatera, Jawa dan Kalimantan. Penilaian ini didasarkan atas banyaknya permintaan dari luar negeri dengan harga yang cukup tinggi, sehingga merupakan salah satu sumber penghasil devisa.

Untuk memenuhi permintaan ikan tersebut hingga sekarang ini masih mengandalkan usaha penangkapan di alam yang hasilnya setiap tahun semakin menurun terutama yang berukuran sesuai permintaan ekspor, yaitu lebih kurang 0,5 kg per ekor (Djajasewaka et al., 1993). Dalam rangka usaha untuk memenuhi permintaan tersebut, salah satu langkah yang perlu ditempuh ialah membudidayakan ikan jenis ini.

Di beberapa negara Asia seperti Thailand dan Malaysia usaha membudidayakan ikan tersebut sudah dimulai beberapa tahun yang lalu, namun sampai sekarang belum mencapai hasil seperti yang diharapkan. Hal ini menurut Tan dan Lam (1973) dan Tavarutmeenagul dan Lim (1988) disebabkan adanya kendala di bidang pembesar-

*) Peneliti pada Loka Penelitian Perikanan Air Tawar Palembang 
an, karena ikan ini tergolong pada ikan buas (predator) yang membutuhkan pakan berprotein yang cukup tinggi dengan harga relatif lebih mahal. Selanjutnya Widiyati (1992) menyatakan bahwa ikan betutu lebih menyukai pakan hidup daripada pakan mati. Namum demikian jika tidak tersedia pakan hidup, benih ikan betutu dapat juga memakan ikan mati yang masih segar (Widiyati et al., 1993).

Penelitian ini bertujuan untuk mengetahui pertumbuhan dan sintasan ikan betutu yang dipelihara dalam hampang serta diberi beberapa jenis pakan alami yang berbeda.

\section{BAHAN DAN METODE}

Ikan uji adalah ikan betutu hasil tangkapan di alam dengan bobot rata-rata 176,2 gram. Kolam lahan rawa luas $400 \mathrm{~m}^{2}$ dengan kedalaman ratarata $1,0 \mathrm{~m}$ yang dikeringkan terlebih dahulu dan dibersihkan dari ikan liar dengan cara menambahkan kapur tohor pada sisa air dan lumpur dasar kolam dosis 1 ton/ha. Kolam disekat dengan hampang bambu menjadi 9 petak dengan ukuran luas $2 \mathrm{~m}^{2}$ per petak dan ditebari benih ikan sebanyak 8 ekor setiap meter persegi. Ikan dipelihara selama 180 hari. Percobaan menggunakan rancangan acak lengkap dengan 3 perlakuan dan 3 ulangan.

Pakan sebagai perlakuan, terdiri atas ikan rucah (Rasbora sp.) hidup, ikan rucah segar dan gondang segar (moluska) yang diberikan sebanyak $3 \%$ dari bobot biomasa ikan diberikan satu kali sehari pada waktu sore hari. Hal ini berdasarkan hasil penelitian pendahuluan yang menunjukkan bahwa ikan betutu lebih aktif makan mulai sore hingga malam hari.

Parameter yang diamati selama percobaan adalah pertambahan bobot dan tingkat sintasan yang dihitung masing-masing berdasarkan Royce (1972) dan Effendie (1979). Mutu air di kolam diamati tiap bulan.

Pertambahan bobot:

$$
\Delta \mathbf{W}=\mathbf{W t}-\mathbf{W o}
$$

di mana:

$\Delta \mathrm{W}=$ Pertambahan bobot

$\mathrm{Wt}=$ Bobot rata-rata akhir

$\mathrm{Wo}_{0}=$ Bobot rata-rata awal

Tingkat sintasan:

$$
S=\frac{N t}{N_{o}} \times 100 \%
$$

di mana:

$\mathrm{S}=$ Sintasan

$\mathrm{Nt}=$ Jumlah akhir hewan uji

No = Jumlah awal hewan uji

\section{HASIL DAN PEMBAHASAN}

\section{Pertambahan Bobot Mutlak}

Data pertambahan bobot mutlak rata-rata individu ikan betutu selama 180 hari percobaan disajikan pada Tabel 1.

Tabel 1. Pertambahan bobot individu ikan betutu selama 180 hari pemeliharaan (gram) Table 1. Individual absolute weigth gain of sand goby during 180-day culture (gram).

\begin{tabular}{lccc}
\hline \multicolumn{1}{c}{$\begin{array}{c}\text { Perlakuan } \\
\text { Treatment }\end{array}$} & $\begin{array}{c}\text { Bobot awal } \\
\text { Initial weight } \\
\text { (Wo) }\end{array}$ & $\begin{array}{c}\text { Bobot akhir } \\
\text { Final weight } \\
\text { (Wt) }\end{array}$ & $\begin{array}{c}\text { Pertambahan bobot } \\
\text { Weight gain } \\
\text { (WW } \mathbf{S D}\end{array}$ \\
\hline Ikan hidup (Life fish) & 176.1 & 458.3 & $282.2 \pm 12.31$ \\
$\begin{array}{l}\text { Rucah segar (Fresh } \\
\text { trash fish) }\end{array}$ & 177.0 & 380.1 & $203.1 \pm 17.15$ \\
$\begin{array}{l}\text { Gondang segar (Fresh } \\
\text { mollusc) }\end{array}$ & 175.5 & 345.5 & $170.0 \pm 3.04$ \\
\hline
\end{tabular}


Pertambahan bobot ikan yang diberi pakan ikan hidup selama 180 hari pemeliharaan adalah yang terbesar $(282,2 \mathrm{~g})$, kemudian yang diberi pakan ikan rucah segar (203,1 g) dan pertambahan bobot terendah pada perlakuan pakan "gondang segar" (170 g). Hasil uji sidik ragam menunjukkan bahwa ketiga perlakuan meng hasilkan pertambahan bobot yang berbeda sangat nyata $(\mathrm{P}<0,01)$.

Hal ini disebabkan ikan betutu bersifat predator yang lebih menyukai makanan hidup dibandingkan dengan yang mati walaupun masih dalam keadaan segar. Pemberian pakan pada ketiga perlakuan sebanyak $3 \%$ dari biomasa per hari dan pakan tidak segera habis pada saat diberikan. Sisa pakan hidup masih bisa dimakan pada kesempatan berikutnya tetapi sisa pakan ikan rucah terutama "gondang" cepat berubah aroma dan membusuk sehingga tidak dimakan oleh ikan. Jumlah pakan yang tidak dimakan (tersisa) rata-rata setiap hari untuk pakan rucah segar dan gondang masing-masing $15 \%$ dan $25 \%$.

Analisis nutrisi dari bahan pakan yang digunakan tertera pada Tabel 2 .

Bila dihubungkan dengan hasil analisis nutrisi pakan ikan rucah hidup dan pakan ikan rucah segar (Tabel 2 ), kandungan nutrisi kedua jenis pakan tersebut sama tetapi pertambahan bobot ikan pada perlakuan ikan rucah hidup lebih tinggi dibanding perlakuan rucah segar. Kandungan protein pada pakan "gondang" segar lebih tinggi dibanding kandungan protein pada pakan hidup dan rucah segar, tetapi dilihat dari hasil pertambahan bobot ikan yang didapat, perlakuan pakan "gondang" adalah yang paling rendah di antara ketiga perlakuan tersebut.

Dengan demikian dapat dikatakan bahwa perbedaan pertambahan bobot ini disebabkan oleh efisiensi pemberian pakan dan perlakuan pakan. Pemberian ikan hidup lebih efesien dibandingkan dengan perlakuan pakan ikan rucah segar dan paling tidak efisien pada perlakuan pakan "gondang", di mana lebih banyak pakan yang tidak dimakan yang berarti pemberian pakan tersebut lebih tidak efisien.

Tingkat efisiensi penggunaan pakan ini disebabkan oleh beberapa sifat ikan betutu, yaitu lebih menyukai pakan hidup, lebih aktif mencari makan pada malam hari, gerakan dan cara makan lamban dan lebih suka membenamkan diri dalam lumpur dasar kolam.

\section{Tingkat Sintasan}

Data tingkat sintasan ikan betutu dapat dilihat pada Tabel 3 .

Tingkat sintasan ikan betutu pada masingmasing perlakuan cukup tinggi, yaitu berkisar 97,91-100\%. Hal ini disebabkan ukuran ikan tebar yang cukup besar dan sebelum ditebar diadaptasikan terlebih dahulu baik terhadap lingkungan maupun pakan sesuai dengan per-lakuan.

Tabel 2. Bahan dan komposisi nutrisi pakan (\%) *)

Table 2. Ingredient and nutritional composition of diets (\%) *)

\begin{tabular}{lccc}
\hline \multirow{2}{*}{$\begin{array}{c}\text { Bahan } \\
\text { (Ingredient) }\end{array}$} & \multicolumn{3}{c}{ Jenis pakan (Kind of feed) } \\
\cline { 2 - 4 } & $\begin{array}{c}\text { Ikan hidup } \\
\text { (Life fish) }\end{array}$ & $\begin{array}{c}\text { Ikan rucah } \\
\text { (Trash fish) }\end{array}$ & $\begin{array}{c}\text { Gondang segar } \\
\text { (Fresh mollusc) }\end{array}$ \\
\hline Protein kasar (Crude protein) & 16.64 & 16.64 & 18.83 \\
Lemak (Fat) & 4.84 & 4.84 & 1.54 \\
Karbohidrat (Carbohidrate) & 1.35 & 1.35 & 6.28 \\
Kadar air (Moisture) & 75.06 & 75.06 & 71.60 \\
\hline
\end{tabular}

*) Hasil analisis laboratorium Balai Industri Palembang (Susanto, 1995) 
Tabel 3. Tingkat sintasan (\%) ikan betutu (Oxyeleotris marmorata Btkr) selama 180 hari pemeliharaan. Table 3. Survival rate (\%) of sand goby.(Oxyeleotris marmorata Blkr) during 180-day experiment.

\begin{tabular}{cccc}
\hline \multirow{2}{*}{$\begin{array}{c}\text { Ulangan } \\
\text { Replication }\end{array}$} & $\begin{array}{c}\text { Ikan hidup } \\
\text { Life fish }\end{array}$ & $\begin{array}{c}\text { Ikan rucah } \\
\text { Trash fish }\end{array}$ & $\begin{array}{c}\text { Gondang segar } \\
\text { Fresh mollusc }\end{array}$ \\
\cline { 2 - 4 } & 100 & 100 & 100 \\
2 & 100 & 93.75 & 100 \\
3 & 100 & 100 & 100 \\
Rata-rata (Means) & 100 & 97.91 & 100 \\
\hline
\end{tabular}

Tingginya sintasan juga dipengaruhi ada tidaknya ikan liar yang dapat berfungsi sebagai kompetitor maupun predator.

Pada Tabel 4 terlihat bahwa kualitas air selama berlangsungnya penelitian masih dalam batas kebutuhan normal bagi kehidupan ikan betutu. Hal ini terbukti dari tingginya tingkat sintasan betutu, yakni berkisar $97-100 \%$. Selanjutnya berdasarkan pernyataan Pescod (1973) dan Boyd (1979) masing-masing mengemukakan bahwa nilai kualitas air yang baik untuk kehidupan ikan, yakni: $\mathrm{pH}$ berkisar 6,5-8,5; oksigen terlarut lebih tinggi dari 2 ppm; $\mathrm{CO} 2$ lebih rendah dari $20 \mathrm{ppm}$. Varikul dan Sritongsak (1980) menyatakan bahwa suhu air yang optimal bagi kehidupan ikan air tawar berkisar $24-30^{\circ} \mathrm{C}$ untuk daerah subtropik dan $26-32^{\circ} \mathrm{C}$ untuk daerah tropis.

\section{KESIMPULAN}

Pakan hidup memberikan pertambahan bobot individu yang paling baik dibandingkan dengan pemberian pakan rucah segar dan gondang.

Tingkat sintasan ikan betutu pada ketiga perlakuan selama penelitian cukup tinggi, yaitu berkisar $97,91-100 \%$.

Tabel 4. Parameter kualitas air selama 180 hari pemeliharaan.

Table 4. Water quality parameters during 180-day rearing period.

\begin{tabular}{|c|c|c|}
\hline Parameter & & Nilai (Value) \\
\hline DO & $(\mathrm{ppm})$ & $3.52-7.3$ \\
\hline $\mathrm{CO}_{2}$ & $(\mathrm{ppm})$ & $3.82-7.8$ \\
\hline $\mathrm{pH}$ & & $6.0 \cdot 7.5$ \\
\hline Suhu air (Water temperature) & $\left({ }^{\circ} \mathrm{C}\right)$ & $24.00-28.00$ \\
\hline
\end{tabular}




\section{DAFTAR PUSTAKA}

Boyd C.E. 1979. Water quality in warmwater fishpond Departement of Fisheries and Allied Aquakulturist, Auburn University Alabama, p:70-73.

Djajasewaka, H; A. Widiyati dan E.Tarupay. 1993. Pematangan gonada induk ikan betutu (Oxyeleotris marmorata $\mathrm{Blkr}$ ) dengan pemberian berbagai jenis pakan. Prosiding Seminar Hasil Penelitian Perikanan Air Tawar 1992/1993.

Effendie, M.I. 1979. Metode biologi perikanan Penerbit Yayasan Dwi Sri Bogor.

Lie, S.F. 1969. A Study on some biological aspect of Oxyeleotris marmorata Blkr found in Singapore, part two, Departement of Zoologi, University of Singapore. $66 \mathrm{p}$.

Mulyono, D. 1990. Mungkinkah ikan betutu atau ikan malas menjadi primadona. Dinas Perikanan Tk.I Kalimantan Timur (18) halaman 49-54.

Pescod, MD. 1973. Investigation of aational affluence and stream standard for tropical countris. AIT P.O. Box 2754 Bangkok, Thailand U.S Army Research and Development Group. Far East APO San Fransisco 96343. 59 pp.
Royce.W.F. 1972. Introduction to the fishery sciences. Academic Press. Inc. New York london.

Tan, O.K.K dan T.J. Lam. 1973. Induced breeding and rearing of sand goby (Oxyeleotris marmorata $\mathrm{Blkr}$ ) fry. Aquaculture,69: 299-306

Tavarutmaneegul, P. dan C.K. Lim. 1988. Breeding and rearing of sand goby (Oxyeleotris marmorata Blkr) fry. Aquaculture, 69: 299-305.

Varikul, V. and C. Sritongsak. 1980. A Review of induced finfish breeding practices in Thailand: Presented at the IDRC Workshop on induced Fish Breeding, Singapore, Nov.25-18, 1980.

Widiyati, A. 1992. Tehnik pembenihan ikan betutu (Oxyeleotris marmorata Blkr). Makalah disampaikan dalam Aplikasi Paket Teknologi Pertanian. BIP Kalimantan Barat, Pontianak, Januari 1992.

Widiyati, A.; H.Djajasewaka dan E.Tarupay. 1993. Pengaruh pemberian pakan buatan, pakan alami dan campuran keduanya terhadap pertumbuhan benih ikan betutu (Oxyelecunlsotris marmorata Blkr). Prosiding Seminar Hasil Penelitian Perikanan Air Tawar 1992/1993. 